\title{
Clodronate inhibits adrenocortical cell proliferation and P450c21 activity
}

\author{
M Fassnacht, A Franke', A Dettling, S Hahner, M Zink, S Wudy² \\ and B Allolio \\ Department of Medicine, Endocrine and Diabetes Unit, University of Wuerzburg, Germany \\ ${ }^{1}$ Department of Surgery, Central Military Hospital of the Armed Medical Forces, Koblenz, Germany \\ ${ }^{2}$ Department of Paediatrics, University of Giessen, Germany \\ (Requests for offprints should be addressed to M Fassnacht, Department of Medicine, Endocrine and Diabetes Unit, University of Wuerzburg, \\ 97080 Würzburg, Germany; Email: M.Fassnacht@medizin.uni-wuerzburg.de)
}

\begin{abstract}
Bisphosphonates (BPs), specific inhibitors of osteoclasts, are well established in the management of skeletal metastases in breast cancer. Recent studies have suggested that these compounds may also directly influence tumor cell proliferation. As adrenocortical cancer frequently leads to bone metastases, we investigated the effects of clodronate (CLO) in the human adrenocortical cancer cell line NCI-H295 and in primary cultures of bovine adrenocortical cells. Both the non-amino BP CLO and the amino BP pamidronate (PAM) exhibited a dose-dependent antiproliferative effect in both cell types (cell viability in NCI-H295 cells: $100 \mu \mathrm{M}$ CLO: $98 \pm 8 \% ; 500 \mu \mathrm{M}$ CLO $76 \pm 6 \% ; 1000 \mu \mathrm{M}$ CLO $53 \pm 2 ; 10 \mu \mathrm{M}$ PAM $96 \pm 3 \%$; $50 \mu \mathrm{M}$ PAM $46 \pm 6 \% ; 100 \mu \mathrm{M}$ PAM $11 \pm 1 \%$ vs untreated control cells: $100 \pm 10 \% ; P<0 \cdot 01)$. FACS analysis in NCI-H295 cells treated with either CLO or PAM demonstrated both apoptotic and necrotic cell death. However, while during PAM treatment cell number and
\end{abstract}

hormone secretion decreased in parallel, we observed specific impairment of steroidogenesis in the presence of CLO with a dose-dependent increase in the $17-\mathrm{OH}-$ progesterone/cortisol ratio $(100 \mu \mathrm{M}$ CLO $134 \pm 30 \%$; $500 \mu \mathrm{M}$ CLO $284 \pm 10 \% ; 1000 \mu \mathrm{M}$ CLO $545 \pm 130 \%$ vs $100 \pm 20 \%$ in control cells; $P<0 \cdot 01)$. Further analysis in ACTH-stimulated bovine adrenal cells using stable isotope dilution/gas chromatography-mass spectrometry demonstrated CLO-induced inhibition of adrenal 21-hydroxylase (P450c21) activity leading to a dose-dependent increase in the 17-OH-progesterone/11-deoxycortisol ratio.

In conclusion, we demonstrate a dose-dependent antiproliferative effect of CLO and PAM in adrenocortical cells. In addition, for the first time, we describe a suppressive effect of CLO on steroidogenesis via inhibition of adrenal 21-hydroxylase (P450c21) activity.

Journal of Endocrinology (2002) 174, 509-516

\section{Introduction}

Bisphosponates (BPs) are analogs of pyrophosphate with a potent inhibitory effect on bone resorption (Sahni et al. 1993, Rodan \& Fleisch 1996, Fleisch 1998, Russell \& Rogers 1999). While a direct effect of BPs on osteoclasts has been repeatedly demonstrated, recent studies have reported specific effects also in other cell types like macrophages (Frith et al. 1997, Luckman et al. 1998a) and some tumor cell lines (Shipman et al. 1997, Aparicio et al. 1998, Fromigue et al. 2000, Senaratne et al. 2000, Lee et al. 2001, Sonnemann et al. 2001). BPs have an established role in the prevention and therapy of osteolytic lesions in patients with malignant diseases like multiple myeloma (Berenson et al. 1996, Berenson 1997, Kanis \& McCloskey 2000) or breast cancer (Hortobagyi et al. 1996, 1998, Lipton 2000, Pavlakis \& Stockler 2002). According to a recent Cochrane review clodronate (CLO) and pamidronate (PAM) should be the preferred agents in this situation (Djulbegovic et al. 2001). Moreover, results of some clinical trials suggest that BPs (like CLO) may have a direct antitumor effect leading to a survival advantage in patients with breast cancer (Diel et al. 1998, Mundy \& Yoneda 1998) or multiple myeloma (Kanis \& McCloskey 2000).

At the cellular level one of the actions of BPs is to induce apoptosis. Interestingly, two different molecular pathways contribute to this apoptotic activity of BPs. CLO and other non-amino BPs induce both necrotic and apoptotic cell death after metabolization of the drug to a nonhydrolyzable, but cytotoxic ATP analog (Frith et al. 1997, Fleisch 1998, Benford et al. 1999, Rogers et al. 2000). In contrast, the nitrogen-containing BPs, such as PAM and alendronate inhibit the intracellular mevalonate pathway enzyme, farnesyl diphosphate synthase, and have been reported to lead to apoptosis (Luckman et al. 1998a,b, 
Reszka et al. 1999, van Beek et al. 1999a, Fisher et al. 2000, van Beek et al. 2002). In addition, other mechanisms such as effects on the cytoskeleton and membrane structures by inhibition of protein geranylgeranylation have recently been described (Coxon et al. 2000, 2001, Halasy-Nagy et al. 2001).

Adrenocortical carcinoma is a rare and highly malignant tumor with an incidence of 1:1.7 million/year (Nader et al. 1983). At the time of diagnosis $70 \%$ of patients suffer from advanced disease with local invasion or distant metastases (Soreide et al. 1992). Next to lung and liver, the skeleton is the most frequent localization of disseminated disease. The prognosis in advanced adrenocortical carcinoma is poor and new treatment options are urgently needed. At least $50 \%$ of all patients with adrenocortical carcinoma suffer from cortisol hypersecretion leading to Cushing's syndrome (Schteingart \& Homan 2001).

Here we report antiproliferative activity of BPs in the human adrenocortical carcinoma cell line NCI-H295. In addition, CLO, but not PAM, specifically impairs adrenal steroidogenesis by inhibition of the 21-hydroxylase enzyme (P450c21) in NCI-H295 cells and in bovine adrenocortical cells.

\section{Materials and Methods}

\section{Materials}

CLO was obtained from Roche (Grenzach-Wyhlen, Germany), and PAM and synthetic adrenocorticotropin $\left(\mathrm{ACTH}_{1-24}\right)$ were purchased from Novartis Pharma (Nürnberg, Germany). RPMI 1640, MEM medium, fetal calf serum (FCS), horse serum (HS), bovine serum albumin (BSA) and trypan blue stain were supplied by Life Technologies (Eggenstein, Germany), and 3(4,5-dimethylthiazol-2-yl)-2,5-diphenyltetrazoliumbromid (MTT), antibiotics, DMEM/HAM'S F12, collagnease II, desoxyribonuclease I, insulin, transferrin, selenium, glutamine, Hepes and Percoll were purchased from Sigma (Deisenhofen, Germany). All reagents used for flow cytometry were derived from Becton Dickinson (Heidelberg, Germany).

\section{Cell culture}

The adrenocortical cancer cell line NCI-H295 (Gazdar et al. 1990) was obtained from the American Type Culture Collection (ATCC, Rockville, MD, USA). The cells were available in an adherent and a suspension variant. The adherent cells were maintained in DMEM/HAM'S F12 medium supplemented with transferrin, insulin, selenium and 5\% FCS and used for the MTT assays. The suspension cells were grown in RPMI 1640 medium supplemented with transferrin, insulin, selenium and 5\% FCS as described previously (Fassnacht et al. 1998, 2000) and were used for flow cytometry analysis. Both variants of cells were grown at $37^{\circ} \mathrm{C}$ under an atmosphere of $5 \%$ $\mathrm{CO}_{2} / 95 \%$ air. For experiments, the FCS concentration was reduced to $2 \%$.

The primary culture of bovine adrenocortical cells was performed as described in detail by Weber and Michl (1996). Briefly, adrenal glands from 2- to 3-year-old steers were obtained from the local slaughterhouse. The tissue was dissected and cells of the zona fasciculata and zona reticularis were obtained by digestion with collagenase II and desoxyribonuclease I. To purify dissociated cells, and to remove contaminating red blood cells and cell debris, a Percoll centrifugation was performed. The final cell pellet was resuspended in DMEM/HAM'S F12 medium supplemented with 10\% FCS, 5\% HS and antibiotics. Cells were plated in $75 \mathrm{~cm}^{2}$ flasks in a concentration of $10^{6}$ cells/ml. Medium was changed after $24 \mathrm{~h}$ to remove cell debris and unattached cells. During the following days, medium was replenished every $24-48 \mathrm{~h}$. On day 3 (72 h after seeding) the experiments commenced and cells were incubated with different doses of BPs.

The colon carcinoma cell line, HT-29 (von Kleist et al. 1975) and the prostate carcinoma cell line, LNCaP (Horoszewicz et al. 1983) were obtained from ATCC. HT-29 cells were maintained in MEM medium supplemented with glutamine, Hepes and 10\% FCS. LNCaP cells were grown in RPMI 1640 medium and 10\% FCS. The breast cancer cell line, T47D (Westley \& Rochefort 1980) was obtained from the European Collection of Animal Cell Cultures (ECACC, Salisbury, UK) and maintained in RPMI 1640 medium supplemented with glutamin, insulin and 10\% FCS. The ovarian cancer cell line, OVCAR-3 (Hamilton et al. 1983) was purchased from the Cell Line Service (CLS, Heidelberg, Germany) and the cells were grown in MEM medium with glutamine and 10\% FCS.

\section{Dye exclusion assay}

Cells were seeded at an initial concentration of $10^{6}$ cells $/ \mathrm{ml}$ into six-well cell culture plates. Drugs were added at specified concentrations. At various time points, viability was determined by trypan blue staining (Duerst $\&$ Frantz 1985). The total number of viable cells was calculated and the percentage of viable cell recovery in the bisphosphonate-treated groups was determined by comparison with untreated control cells.

\section{MTT assay}

Cells were seeded into 96-well microtiter plates at a density of 50000 cells/well. Twenty-four hours after inoculation, CLO (final concentration of 100-2000 $\mu \mathrm{M}$ ) or PAM $(1-100 \mu \mathrm{M})$ was added to the wells $(n=8$ replicates). The cells were then incubated for a further $72 \mathrm{~h}$ followed by addition of MTT reagent $(5 \mathrm{mg} / \mathrm{ml}$ stock solution) in a final concentration of $0.5 \mathrm{mg} / \mathrm{ml}$. After incubation at $37^{\circ} \mathrm{C}$ for $3 \mathrm{~h}$, the product was dissolved by 
addition of $100 \mu \mathrm{l}$ cell lysis buffer (isopropanol with $\mathrm{HCl}$ ), and absorbance of the wells was measured at $570 \mathrm{~nm}$ using an ELISA plate reader (400 SF, SLT Lab Instruments, Crailsheim, Germany).

\section{Flow cytometry analysis}

NCI-H295 cells were cultured as described above with different concentrations of CLO (500-1000 $\mu \mathrm{M})$ and PAM $(50-100 \mu \mathrm{M})$ for 4-48 h. After incubation, cells were washed twice with sterile PBS containing $0 \cdot 1 \%(\mathrm{w} / \mathrm{v})$ BSA at room temperature. Then $1 \times 10^{6}$ cells were stained using $0 \cdot 25 \mu \mathrm{g} 7$-amino-actinomycin $\mathrm{D}(7-\mathrm{AAD})$ as a nucleic acid dye and $5 \mu \mathrm{l}$ of a phycoerythrin (PE)-conjugated antibody to annexin $\mathrm{V}$ at a total volume of $100 \mu \mathrm{l}$. After an incubation time of $10 \mathrm{~min}$ in the dark, $400 \mu \mathrm{l}$ PBS containing $0 \cdot 1 \%$ BSA $(\mathrm{w} / \mathrm{v})$ were added and cells were analyzed by flow cytometry. Using Cell Quest software and a Facscalibur flow cytometer (both Becton Dickinson) $1 \times 10^{5}$ cells were gated in a dot plot forward scatter (FSC) versus side scatter (SSC). In a dot plot fluorescence 3 (7-AAD) versus fluorescence 2 (annexin V-PE) quadrant statistics were taken to detect double positive cells (7-AAD and annexin $\mathrm{V}$, late apoptotic - effectively dead - cells) as well as cells negative for 7-AAD and positive for annexin $\mathrm{V}$ (early apoptotic cells). All data are given as percentage (geometric mean \pm S.D.) of gated cells.

\section{Steroid determination}

Adrenocortical cells were incubated for $48 \mathrm{~h}$ with CLO $(100-2000 \mu \mathrm{M})$ or PAM $(1-100 \mu \mathrm{M})$. NCI-H295 cells were also incubated for shorter time periods $(2 \cdot 5$ and $24 \mathrm{~h})$. Each experiment was performed in triplicate. ACTH stimulation was performed only in bovine adrenocortical cells, because the human NCI-H295 cells express ACTH receptor at a very low level and these cells are, therefore, less suitable for investigating ACTH-induced effects on steroidogenesis. ACTH incubation $(4 \mathrm{~h})$ was performed after $48 \mathrm{~h}$ of pre-treatment with $0,100,500$ or $1000 \mu \mathrm{M}$ CLO. The media were changed and the fresh media without BPs were supplemented with $10 \mathrm{nM}$ ACTH and the cells were incubated for $4 \mathrm{~h}$. At the end of the incubation period steroid hormones (cortisol and 17-OH-progesterone) were determined in the cell supernatant by commercially available radioimmunoassays (DPC Biermann, Bad Nauheim, Germany). Additionally, in bovine adrenal cells after ACTH stimulation, cortisol, 11-deoxycortisol, 17-hydroxy-progesterone, 17-hydroxypregnenolone, androstendione, and testosterone were determined by stable isotope dilution/gas chromatographymass spectrometry (GC-MS) as described elsewhere (Wudy et al. 2001). In brief, cell supernatant was equilibrated with internal standard (deuterium-labeled analogs of analytes). After solvent extraction and purification, heptafluorobutyrate derivatives were prepared. Gas
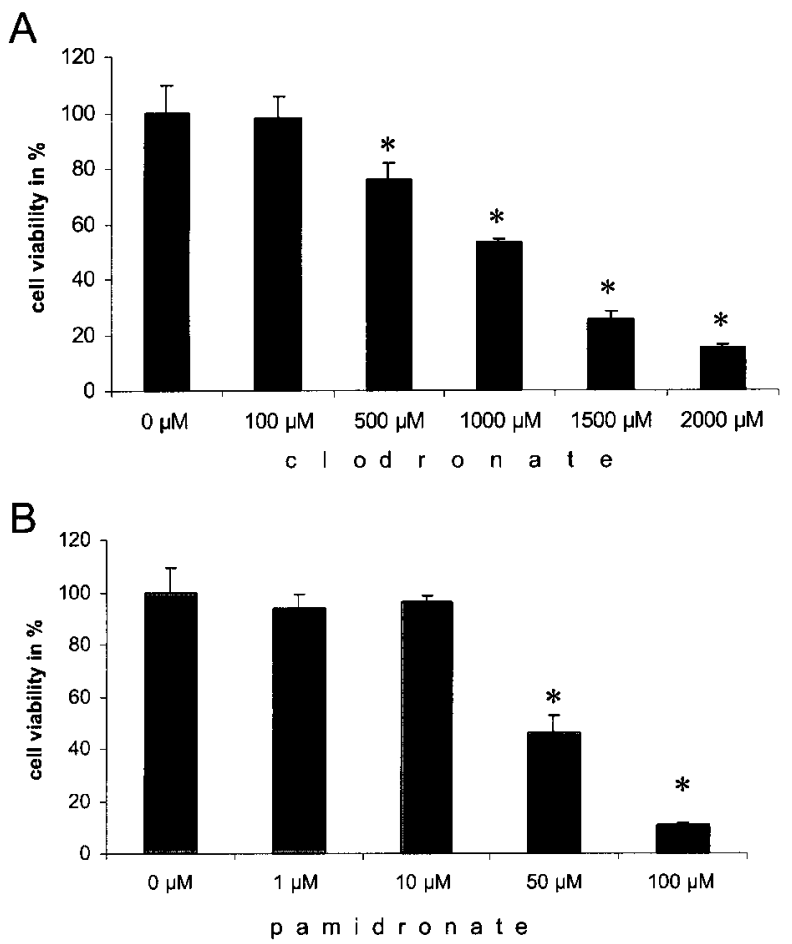

Figure 1 Dose-dependent effect of bisphosphonates on cell viability in the human $\mathrm{NCl}-\mathrm{H} 295$ cell line as measured by the MTT assay. Cells were treated with $100-2000 \mu \mathrm{M}$ clodronate (A) or 1-100 $\mu \mathrm{M}$ pamidronate (B) for $96 \mathrm{~h}$. Results are given as a percentage of untreated control cells $(100 \%)$ and are shown as means \pm S.D. ${ }^{*} P<0 \cdot 01$ compared with control cells.

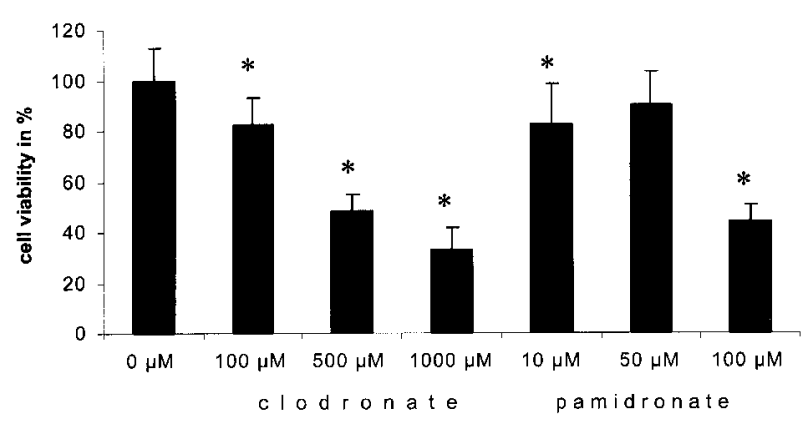

Figure 2 Dose-dependent effect of 96-h incubation with clodronate $(100,500$ or $1000 \mu \mathrm{M})$ and pamidronate $(10,50$ or $100 \mu \mathrm{M})$ on cell viability in bovine adrenocortical cells as measured by the MTT assay. Results are given as a percentage of untreated control cells $(100 \%)$ and are shown as means \pm S.D. ${ }^{\star} P<0.01$ compared with control cells.

chromatography was carried out on an Agilent 6890 series GC housing an OV-1 fused silica capillary $(25 \mathrm{~m} \times 0 \cdot 2 \mathrm{~mm}$, film $0 \cdot 1 \mu \mathrm{m}$, Macherey-Nagel, Düren, Germany) coupled with an Agilent 5973 mass selective detector operated in the selected ion-monitoring mode. For computerized quantification, peak areas of specific ions of analytes and their corresponding internal standards were 
Table 1 Effects of clodronate and pamidronate on cell viability in human adrenocortical NCl-H295 cells measured by annexin and 7-AAD staining and flow cytometry analysis. Cells were incubated for 4, 6, 24 or 48 hours with 500 or $1000 \mu \mathrm{M}$ clodronate or 50 or $100 \mu \mathrm{M}$ pamidronate. Cells stained only for Annexin V indicate early apoptosis, 7-AAD-positive (pos.) cells indicate necrosis. Both annexin V-and 7-AAD-positive cells indicate late apoptosis, effectively dead cells. Results (means \pm S.D.) are given as percentage of all gated cells (100\%)

\begin{tabular}{|c|c|c|c|c|}
\hline & Viable cells & $\begin{array}{l}\text { Annexin V pos. } \\
+7-A A D \text { neg. }\end{array}$ & $\begin{array}{l}\text { Annexin V pos. } \\
+7-A A D \text { pos. }\end{array}$ & $\begin{array}{l}\text { Annexin V neg. } \\
+7-A A D \text { pos. }\end{array}$ \\
\hline \multicolumn{5}{|l|}{4 hours } \\
\hline $1000 \mu \mathrm{M}$ clodronate & $79 \cdot 2 \pm 0 \cdot 9^{*}$ & $7 \cdot 6 \pm 1 \cdot 3$ & $9 \cdot 6 \pm 0 \cdot 8^{*}$ & $3 \cdot 5 \pm 0 \cdot 7$ \\
\hline $100 \mu \mathrm{M}$ pamidronate & $87 \cdot 7 \pm 1 \cdot 6$ & $7 \cdot 0 \pm 2 \cdot 2$ & $3 \cdot 9 \pm 1 \cdot 7$ & $1 \cdot 4 \pm 0 \cdot 7$ \\
\hline \multicolumn{5}{|l|}{6 hours } \\
\hline $100 \mu \mathrm{M}$ pamidronate & $84 \cdot 6 \pm 2 \cdot 2$ & $3 \cdot 0 \pm 1 \cdot 1$ & $6 \cdot 7 \pm 1 \cdot 2$ & $5 \cdot 6 \pm 0 \cdot 6$ \\
\hline \multicolumn{5}{|l|}{24 hours } \\
\hline Untreated cells & $72 \cdot 0 \pm 3 \cdot 2$ & $8 \cdot 2 \pm 1 \cdot 2$ & $12 \cdot 8 \pm 2 \cdot 2$ & $6 \cdot 9 \pm 2 \cdot 2$ \\
\hline $1000 \mu \mathrm{M}$ clodronate & $60 \cdot 9 \pm 5 \cdot 7^{*}$ & $10 \cdot 3 \pm 1 \cdot 3$ & $20 \cdot 1 \pm 4 \cdot 3$ & $8 \cdot 5 \pm 1 \cdot 5$ \\
\hline $100 \mu \mathrm{M}$ pamidronate & $55 \cdot 9 \pm 5 \cdot 8^{*}$ & $9 \cdot 6 \pm 0 \cdot 8$ & $22 \cdot 4 \pm 5 \cdot 5^{*}$ & $12 \cdot 0 \pm 4 \cdot 4$ \\
\hline \multicolumn{5}{|l|}{48 hours } \\
\hline Untreated cells & $77 \cdot 1 \pm 1 \cdot 9$ & $7 \cdot 7 \pm 2 \cdot 1$ & $9 \cdot 3 \pm 0 \cdot 6$ & $5 \cdot 9 \pm 0 \cdot 7$ \\
\hline
\end{tabular}

neg., negative.

${ }^{*} P<0.05$ compared with untreated cells.

recorded. Dehydroepiandrosterone, androstandiol and dihydrotestosterone levels were below the limit of detection of the method.

\section{Statistical analysis}

All results are expressed as means \pm S.D. Significance of differences were evaluated by ANOVA (Statview 4.51, SAS Institue Inc., Cary, NC, USA). A value of $P<0 \cdot 05$ was considered statistically significant.

\section{Results}

\section{Cell proliferation, apoptosis and necrosis}

Treatment of the adrenocortical cancer cell line NCIH295 led to a dose-dependent decrease of cell viability as measured by the MTT assay (Fig. 1A). This effect was paralleled by a reduced cell number as determined by trypan blue staining after an incubation time of $48 \mathrm{~h}$ $(100 \mu \mathrm{M}$ CLO: $99 \pm 12 \%, 500 \mu \mathrm{M}$ CLO: $82 \pm 11 \%$, $1000 \mu \mathrm{M}$ CLO: $66 \pm 9 \%$ compared with untreated control cells: $100 \pm 10 \% ; P<0 \cdot 01)$. Incubation of the cells with the amino BP PAM caused a comparable decrease in cell viability but at much lower concentrations (Fig. 1B). Similar dose-dependent antiproliferative effects were detected in bovine adrencortical cells (Fig. 2).

To exclude a non-specific toxic effect, we evaluated the cell viability in the MTT assay in four different non-adrenal cancer cell lines after incubation with
$1000 \mu \mathrm{M}$ CLO. Significant suppression of cell viability was seen in the breast cancer cell line T47D $(1000 \mu \mathrm{M}$ CLO $38 \pm 5 \%$ compared with untreated control cells $100 \pm 7 \% ; P<0 \cdot 01)$ and in the ovarian carcinoma cell line OVCAR-3 $(1000 \mu \mathrm{M}$ CLO $83 \pm 4 \%$ compared with untreated control cells $100 \pm 9 \% ; P<0 \cdot 01)$. No reduction in cell viability was seen in the colon carcinoma cell line HT-29 $(1000 \mu \mathrm{M}$ CLO $115 \pm 6 \%$ compared with untreated control cells $100 \pm 7 \%$ ) and in the prostate cancer cell line LNCaP $(1000 \mu \mathrm{M}$ CLO $102 \pm 11 \%$ compared with untreated control cells $100 \pm 15 \%$ ).

As BPs are known to induce both apoptosis and necrosis in different cells, we analyzed translocation of phosphatidylserine on the outer cell membrane as a sign of apoptosis in NCI-H295 cells by flow cytometry. Forty-eight hours of incubation with CLO or PAM in NCI-H295 cells led to a dose-dependent increase of annexin $\mathrm{V}$ - and 7-AADstaining cells analyzed by flow cytometry (Table 1) indicating apoptotic and necrotic cell death. Similar results were seen after 4, 6 and $24 \mathrm{~h}$ (Table 1).

\section{Hormone secretion}

In both NCI-H295 cells and bovine adrenocortical cells, both CLO and PAM led to a dose-dependent decrease in cortisol secretion. However, further analysis demonstrated different effects of CLO and PAM on steroidogenesis. PAM reduced cortisol and 17-OH-progesterone secretion in parallel with the decrease in cell number with no 

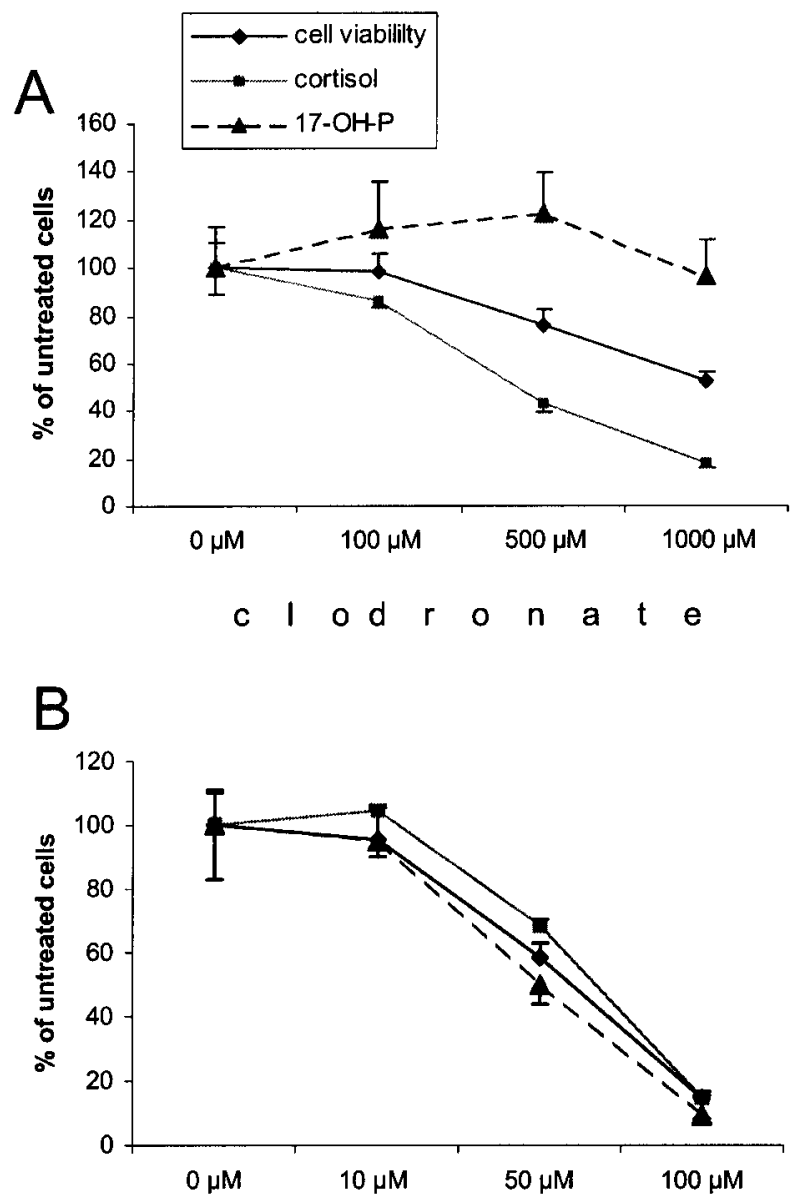

p a m i d r o n a t e

Figure 3 Effects of clodronate (A) and pamidronate (B) on cell viability and hormone secretion in human $\mathrm{NCl}-\mathrm{H} 295$ cells. Cells were incubated for $96 \mathrm{~h}$ with increasing doses of the bisphosphonates as indicated. Cell viability was measured by MTT assay; cortisol and $17-\mathrm{OH}$-progesterone (17-OH-P) secretion were determined in the cell supernatant by radioimmunoassay. Results are given as percentage of untreated control cells (100\%) and are shown as means \pm S.D.

change in the 17-OH-progesterone/cortisol ratio (Fig. 3B). In contrast, cortisol secretion in CLO-treated cells was suppressed, while 17-OH-progesterone secretion remained unaffected or was even increased (Fig. 3A). A similar pattern was seen after $2 \cdot 5$ and $24 \mathrm{~h}$ of incubation. In PAM-treated cells the 17-OH-progesterone/cortisol ratio remained unaffected, while it was significantly increased in cells treated with $1000 \mu \mathrm{M}$ CLO in comparison with untreated control cells $(2.5 \mathrm{~h}: 125 \pm 17 \mathrm{vs}$ $100 \pm 8 \% ; 24$ h: $139 \pm 17$ vs $100 \pm 5 \%$; both $P<0 \cdot 05)$ although this increase was clearly smaller than after longterm incubation $(48 \mathrm{~h})$. To further elucidate the CLOinduced inhibition of steroidogenesis we investigated, in more detail, steroid secretion after ACTH stimulation
(4 h) via GC-MS in bovine adrenocortical cells pre-treated with CLO (48 h). In comparison with control cells not pre-treated with CLO, the ACTH-stimulated 17-OHprogesterone secretion in CLO pre-treated cells was dramatically increased while cortisol secretion increased only slightly. Deoxycortisol secretion increased only slightly, in parallel with cortisol (Table 2 and Fig. 4) indicating inhibition of P450c21 enzyme activity by CLO.

\section{Discussion}

Our study shows a clear antiproliferative activity of both the non-amino BP CLO and the amino BP PAM in the human adrenocortical cancer cell line NCI-H295 and in primary culture of bovine adrenocortical cells. An intriguing finding was the unexpected observation of a differential effect of PAM and CLO on steroidogenesis: while the amino BP PAM reduced both cortisol and 17-OH-progesterone secretion in parallel with its antiproliferative activity, there was evidence for specific inhibition of adrenal 21-hydroxylase activity by CLO. This was demonstrated in both NCI-H295 cells and in primary cultures of bovine adrenocortical cells by an increased 17-OH-progesterone/cortisol ratio.

Direct antiproliferative activity of BPs has been reported recently in a variety of tumor cell lines (Shipman et al. 1997, Aparicio et al. 1998, Busch et al. 1998, Fromigue et al. 2000, Senaratne et al. 2000, Lee et al. 2001, Sonnemann et al. 2001). However, as has been observed in this study for the colon cancer cell line HT29 and the prostate cancer cell line LNCaP, not all tumor cells are equally sensitive to antiproliferative effects of BPs, suggesting specific mechanisms of action. Possibly the ability to internalize bisphosphonates is different in these cell lines. Moreover, there is evidence that amino BPs and nonamino BPs exert differential effects in both osteoclasts and tumor cells. Frith et al. (1997) demonstrated that the non-amino BP CLO can be metabolically incorporated into a nonhydrolyzable analog of ATP in the cytoplasm of J774 macrophages in vitro. The intracellular accumulation of this metabolite may be responsible for the observed growth inhibitory effect. This cytotoxic mechanism has also been demonstrated for other non-amino BPs (Benford et al. 1999) and leads to a combination of apoptosis and necrosis (Fromigue et al. 2000). Flow cytometry analysis in our study also indicated such a combination of apoptosis and necrosis in adrenocortical cancer cells after incubation with CLO. Although flow cytometry analysis is not the gold standard to differentiate between apoptosis and necrosis, the increased number of annexin-positive cells after incubation with CLO and PAM clearly suggests an involvement of apoptosis. In contrast, amino BPs like PAM induce apoptosis by inhibition of the mevalonate pathway with consecutive impairment of protein prenylation (Luckman et al. 1998a,b, Benford et al. 1999, Reszka et al. 1999, van Beek et al. 1999a,b, Fisher et al. 2000). 
Table 2 Steroid release in bovine adrenocortical cells pre-treated with clodronate after ACTH stimulation. Cells were pre-treated with or without clodronate $(100-1000 \mu \mathrm{M})$ for $48 \mathrm{~h}$, medium was changed and cells were incubated with $10 \mathrm{nM}$ ACTH for $4 \mathrm{~h}$. Different steroid hormones were determined in the cell supernatant by stable isotope dilution/gas chromatography-mass spectrometry. Hormone levels (means \pm S.D.) are given in $n g / 10^{6}$ cells $/ 4 \mathrm{~h}$

\begin{tabular}{|c|c|c|c|}
\hline Pre-treatment & Cortisol & Deoxycortisol & 17-OH-progesterone \\
\hline Control & $965 \cdot 6 \pm 30 \cdot 9$ & $302 \cdot 5 \pm 14 \cdot 5$ & $47 \cdot 7 \pm 5 \cdot 2$ \\
\hline $100 \mu \mathrm{M}$ CLO & $1223 \cdot 2 \pm 50 \cdot 1^{*}$ & $522 \cdot 4 \pm 6 \cdot 8^{*}$ & $147 \cdot 9 \pm 19 \cdot 9^{*}$ \\
\hline $500 \mu \mathrm{M}$ CLO & $1754 \cdot 6 \pm 87 \cdot 9^{* *}$ & $665 \cdot 8 \pm 6 \cdot 3^{* *}$ & $477 \cdot 4 \pm 67 \cdot 1^{* *}$ \\
\hline $1000 \mu \mathrm{M}$ CLO & $1900 \cdot 4 \pm 88 \cdot 6^{* *}$ & $752 \cdot 9 \pm 35 \cdot 6^{* *}$ & $568 \cdot 8 \pm 44 \cdot 6^{* *}$ \\
\hline
\end{tabular}

\begin{tabular}{l}
$\mathbf{1 7 - O H - p r e g n e n o l o n e}$ \\
\hline $10 \cdot 9 \pm 0 \cdot 6$ \\
$7 \cdot 57 \pm 0 \cdot 6^{*}$ \\
$13 \cdot 0 \pm 1 \cdot 4$ \\
$16 \cdot 3 \pm 1 \cdot 6^{* *}$
\end{tabular}

\begin{tabular}{l} 
Androstendione \\
\hline $31 \cdot 5 \pm 3 \cdot 8$ \\
$43 \cdot 5 \pm 7 \cdot 5$ \\
$54 \cdot 9 \pm 12 \cdot 3^{*}$ \\
$47 \cdot 4 \pm 9 \cdot 4$
\end{tabular}

\begin{tabular}{l} 
Testosterone \\
\hline $0 \cdot 81 \pm 0 \cdot 11$ \\
$1 \cdot 23 \pm 0 \cdot 34$ \\
$1 \cdot 42 \pm 0 \cdot 29^{*}$ \\
$1 \cdot 45 \pm 0 \cdot 1^{*}$
\end{tabular}

${ }^{*} P<0 \cdot 05 ;{ }^{* *} P<0 \cdot 01$ compared with controls.

However, the increased number of 7-AAD-stained cells without any annexin staining suggested that necrosis also contributes to the antiproliferative activity of CLO and PAM in NCI-H295 cells.

In adrenocortical cells the differential effect of the amino BP PAM and the non-amino BP CLO was most strikingly evident from the differential effects on steroidogenesis. NCI-H295 cells are the most suitable model for studying steroidogenesis, since this cell line is the only available human cell line which expresses all major adrenal steroidogenic enzymes and has the ability to produce all the adrenocortical steroids (Gazdar et al. 1990, Staels et al. 1993, Rainey et al. 1994). Due to the diminished response

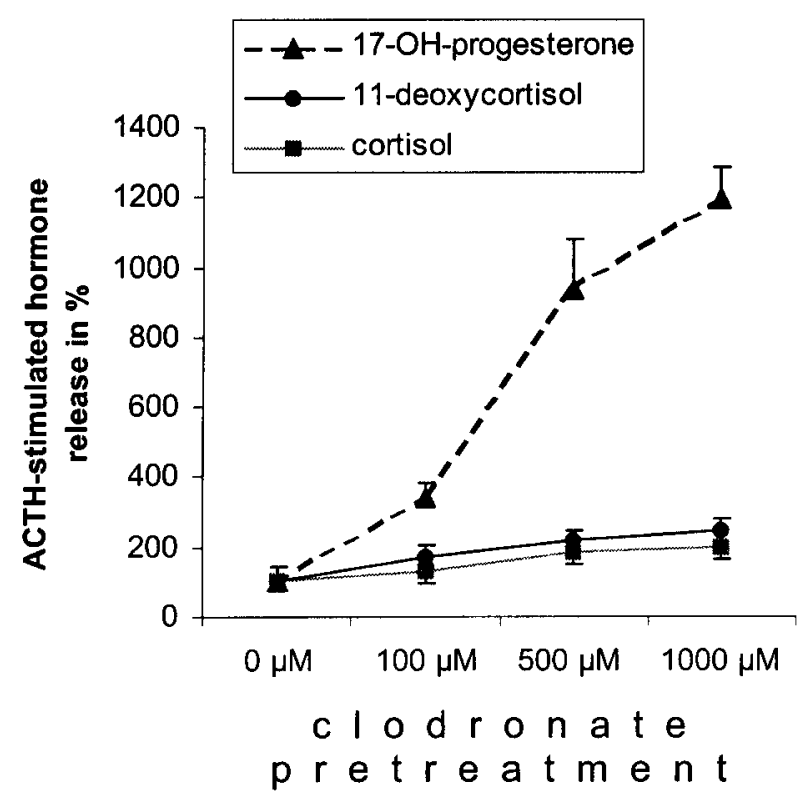

Figure 4 Effect of pre-treatment with clodronate on ACTH-induced hormone secretion in bovine adrenocortical cells. Cells were pre-treated with or without clodronate $(100-1000 \mu \mathrm{M})$ for $48 \mathrm{~h}$, medium was changed and cells were incubated with $10 \mathrm{nM}$ ACTH for $4 \mathrm{~h}$. Cortisol, 11-dexoxycortisol, and 17-OH-progesterone secretion were determined in the cell supernatant by stable isotope dilution/gas chromatography-mass spectrometry. Results (means \pm S.D.) are given as a percentage of hormone secretion of cells not pre-treated with clodronate (100\%). of the NCI-H295 cells to ACTH (Rainey et al. 1993, Mason et al. 1995), we analyzed the changes in the hormone secretion profile after ACTH stimulation in primary cultures of bovine adrenocortical cells. It has been shown that these cells produce large amounts of steroid hormones after incubation with ACTH (Weber \& Michl 1996, Le Roy et al. 2000). In both cell types only CLO exhibited a suppressive activity on cortisol secretion beyond mere reduction in cell number. Further analysis using stable isotope dilution/GC-MS clearly established inhibition of adrenal 21-hydroxylase (P450c21) activity as the cause of the increased 17-OH-progesterone/cortisol ratio (Fig. 4). This effect is already evident at low concentrations $(100 \mu \mathrm{M})$, which do not affect cell viability. This inhibition of the adrenal 21-hydroxylase enzyme was reversible after removal of CLO. After addition of fresh medium (without CLO) CLO pretreated cells showed a higher cortisol response to ACTH than control cells. This is most likely due to partial recovery from enzyme inhibition and the CLO-induced increase in cortisol precursors.

In contrast, steroid secretion in PAM-treated cells strictly paralleled cell number without evidence of specific inhibition of steroidogenic enzymes.

It remains unclear by which mechanism CLO induces the observed inhibition of the adrenal 21-hydroxylase enzyme. The fact that short-time incubation with CLO was less inhibitory may indicate that inhibition of steroidogenesis is mediated indirectly or by metabolites of CLO. It is known that adrenal P450 steroidogenic enzymes are under the control of the ACTH-induced cAMP-proteinkinase A pathway (Staels et al. 1993). Thus, by generating a nonhydrolyzable analog of ATP CLO may impair this signaling cascade. However, it would be expected that impairment of the cAMP system would affect all steroidogenic enzymes. Thus, either the 21-hydroxylase enzyme is more sensitive to changes in the cAMP-system or CLO acts via another mechanism, possibly also by directly interfering with $\mathrm{P} 450 \mathrm{c} 21$ activity.

Our findings may have clinical implications. CLO may be a useful adjuvant treatment in patients with adrenocortical carcinoma and bone metastases. Several studies have found that CLO serum concentrations reach $30 \mu \mathrm{M}$ after a 
single intravenous dose of $300 \mathrm{mg}$ (Yakatan et al. 1982, Hanhijarvi et al. 1989, Hurst \& Noble 1999). Ylitalo et al. (1999) demonstrated that CLO concentrations in serum after orally administered CLO increase dose-dependently. During the maintenance therapy in cancer patients the renal drug clearance seems to be lower than in healthy volunteers (Ylitalo et al. 1999). Moreover, in patients with osteolytic metastases, high doses of CLO (up to $2000 \mathrm{mg}$ orally daily or $1500 \mathrm{mg}$ i.v. every 14-21 days) are given, so that peak serum levels of $200-300 \mu \mathrm{M}$ are likely. In addition, it has been suggested that the effective local concentration of BPs at the site of active bone resorption is much higher than corresponding serum levels due to their high affinity for bone mineral (Sato et al. 1991).

At present, it is not clear whether inhibition of steroidogenesis by CLO is also relevant in vivo in patients receiving CLO. Two of us (M F and A F) volunteered to receive an infusion of a single dose of $1500 \mathrm{mg}$ CLO combined with short ACTH tests $\left(250 \mu \mathrm{g} \mathrm{ACTH}_{1-24}\right)$ prior to and after CLO infusion. After the CLO challenge an increase in the 17-OH-progesterone/cortisol ratio after ACTH stimulation was observed in both cases (to 163\% and 133\% respectively of values prior to CLO infusion). However, as the cortisol response to ACTH was not reduced, this may indicate that, in vivo, significant impairment of adrenocortical function by CLO therapy is unlikely. On the other hand, long-term treatment may lead to chronic exposure and more pronounced impairment. Moreover, some patients may be more susceptible to the inhibitory activity of CLO (e.g. heterozygotes for congenital adrenal hyperplasia), and interaction with other treatment options in tumor patients (e.g. ketoconazole) may lead to impairment in the adrenal stress response. Thus further studies are required to elucidate the effects of chronic CLO treatment on adrenal function in tumor patients.

In summary, we could demonstrate a dose-dependent antiproliferative effect of CLO and PAM in adrenocortical cells. In addition, for the first time, we describe a specific suppressive effect of CLO on steroidogenesis via inhibition of the adrenal 21-hydroxylase enzyme (P450c21) activity.

\section{Acknowledgements}

B Allolio was supported by the Deutsche Forschungsgemeinsschaft (Al 203/7-1).

\section{References}

Aparicio A, Gardner A, Tu Y, Savage A, Berenson J \& Lichtenstein A 1998 In vitro cytoreductive effects on multiple myeloma cells induced by bisphosphonates. Lenkemia 12 220-229.

van Beek E, Pieterman E, Cohen L, Lowik C \& Papapoulos S 1999a Farnesyl pyrophosphate synthase is the molecular target of nitrogen-containing bisphosphonates. Biochemical and Biophysical Research Communications 264 108-111.

van Beek E, Pieterman E, Cohen L, Lowik C \& Papapoulos S 19996 Nitrogen-containing bisphosphonates inhibit isopentenyl pyrophosphate isomerase/farnesyl pyrophosphate synthase activity with relative potencies corresponding to their antiresorptive potencies in vitro and in vivo. Biochemical and Biophysical Research Communications 255 491-494.

van Beek ER, Lowik CW \& Papapoulos SE 2002 Bisphosphonates suppress bone resorption by a direct effect on early osteoclast precursors without affecting the osteoclastogenic capacity of osteogenic cells: the role of protein geranylgeranylation in the action of nitrogen-containing bisphosphonates on osteoclast precursors. Bone 30 64-70.

Benford HL, Frith JC, Auriola S, Monkkonen J \& Rogers MJ 1999 Farnesol and geranylgeraniol prevent activation of caspases by aminobisphosphonates: biochemical evidence for two distinct pharmacological classes of bisphosphonate drugs. Molecular Pharmacology 56 131-140.

Berenson JR 1997 Bisphosphonates in multiple myeloma. Cancer 80 1661-1667.

Berenson JR, Lichtenstein A, Porter L, Dimopoulos MA, Bordoni R, George S, Lipton A, Keller A, Ballester O, Kovacs MJ et al. 1996. Efficacy of pamidronate in reducing skeletal events in patients with advanced multiple myeloma. Myeloma Aredia Study Group. New England Journal of Medicine 334 488-493.

Busch M, Rave-Frank M, Hille A \& Duhmke E 1998 Influence of clodronate on breast cancer cells in vitro. European Journal of Medical Research 3 427-431.

Coxon FP, Helfrich MH, Van't Hof R, Sebti S, Ralston SH, Hamilton A \& Rogers MJ 2000 Protein geranylgeranylation is required for osteoclast formation, function, and survival: inhibition by bisphosphonates and GGTI-298. Journal of Bone and Mineral Research 15 1467-1476.

Coxon FP, Helfrich MH, Larijani B, Muzylak M, Dunford JE, Marshall D, McKinnon AD, Nesbitt SA, Norton MA, Seabra MC et al. 2001 Identification of a novel phosphonocarboxylate inhibitor of Rab geranylgeranyl transferase that specifically prevents Rab prenylation in osteoclasts and macrophages. Journal of Biological Chemistry 276 48213-48222.

Diel IJ, Solomayer EF, Costa SD, Gollan C, Goerner R, Wallwiener D, Kaufmann M \& Bastert G 1998 Reduction in new metastases in breast cancer with adjuvant clodronate treatment. New England Journal of Medicine 339 357-363.

Djulbegovic B, Wheatley K, Ross J, Clark O, Bos G, Goldschmidt H, Cremer F, Alsina M \& Glasmacher A 2001 Bisphosphonates in multiple myeloma (Cochrane Review). Cochrane Database of Systematic Reviews 4 CD003188.

Duerst RE \& Frantz CN 1985 A sensitive assay of cytotoxicity applicable to mixed cell populations. Journal of Immunological Methods 82 39-46.

Fassnacht M, Beuschlein F, Vay S, Mora P, Allolio B \& Reincke M 1998 Aminoglutethimide suppresses adrenocorticotropin receptor expression in the NCI-h295 adrenocortical tumor cell line. Journal of Endocrinology 159 35-42.

Fassnacht M, Hahner S, Beuschlein F, Klink A, Reincke M \& Allolio B 2000 New mechanisms of adrenostatic compounds in a human adrenocortical cancer cell line. European Journal of Clinical Investigation 30 76-82.

Fisher JE, Rodan GA \& Reszka AA 2000 In vivo effects of bisphosphonates on the osteoclast mevalonate pathway. Endocrinology $1414793-4796$.

Fleisch H 1998 Bisphosphonates: mechanisms of action. Endocrine Reviews 19 80-100.

Frith JC, Monkkonen, J, Blackburn GM, Russell RG \& Rogers MJ 1997 Clodronate and liposome-encapsulated clodronate are metabolized to a toxic ATP analog, adenosine 5'-(beta, gamma-dichloromethylene) triphosphate, by mammalian cells in vitro. Journal of Bone and Mineral Research 12 1358-1367.

Fromigue O, Lagneaux L \& Body JJ 2000 Bisphosphonates induce breast cancer cell death in vitro. Journal of Bone and Mineral Research 15 2211-2221. 
Gazdar AF, Oie HK, Shackleton CH, Chen TR, Triche TJ, Myer CE, Chrousos GP, Brennan MF, Stein CA, La Rocca RV 1990 Establishment and characterization of a human adrenocortical carcinoma cell line that expresses multiple pathways of steroid biosynthesis. Cancer Research 50 5488-5496.

Halasy-Nagy JM, Rodan GA \& Reszka AA 2001 Inhibition of bone resorption by alendronate and risedronate does not require osteoclast apoptosis. Bone 29 553-559.

Hamilton TC, Young RC, McKoy WM, Grotzinger KR, Green JA, Chu EW, Whang Peng J, Rogan AM, Green WR \& Ozols RF 1983 Characterization of a human ovarian carcinoma cell line (NIH:OVCAR-3) with androgen and estrogen receptors. Cancer Research 43 5379-5389.

Hanhijarvi H, Elomaa I, Karlsson M \& Lauren L 1989 Pharmacokinetics of disodium clodronate after daily intravenous infusions during five consecutive days. International Journal of Clinical Pharmacology, Therapy and Toxicology 27 602-606.

Horoszewicz JS, Leong SS, Kawinski E, Karr JP, Rosenthal H, Chu TM, Mirand EA \& Murphy GP 1983 LNCaP model of human prostatic carcinoma. Cancer Research 43 1809-1818.

Hortobagyi GN, Theriault RL, Porter L, Blayney D, Lipton A, Sinoff C, Wheeler H, Simeone JF, Seaman J \& Knight RD 1996 Efficacy of pamidronate in reducing skeletal complications in patients with breast cancer and lytic bone metastases. Protocol 19, Aredia Breast Cancer Study Group. New England Journal of Medicine 335 $1785-1791$.

Hortobagyi GN, Theriault RL, Lipton A, Porter L, Blayney D, Sinoff C, Wheeler H, Simeone JF, Seaman J \& Knight RD et al. 1998 Long-term prevention of skeletal complications of metastatic breast cancer with pamidronate. Protocol 19, Aredia Breast Cancer Study Group. Journal of Clinical Oncology 16 2038-2044.

Hurst M \& Noble S 1999 Clodronate: a review of its use in breast cancer. Drugs Aging 15 143-167.

Kanis J \& McCloskey E 2000. Bisphosphonates in multiple myeloma. Cancer 88 3022-3032.

von Kleist S, Chany E, Burtin P, King M \& Fogh J 1975 Immunohistology of the antigenic pattern of a continuous cell line from a human colon tumor. Journal of the National Cancer Institute $\mathbf{5 5}$ $555-560$.

Le Roy C, Li JY, Stocco DM, Langlois D \& Saez JM 2000 Regulation by adrenocorticotropin (ACTH), angiotensin II, transforming growth factor-beta, and insulin-like growth factor I of bovine adrenal cell steroidogenic capacity and expression of ACTH receptor, steroidogenic acute regulatory protein, cytochrome P450c17, and 3 beta-hydroxysteroid dehydrogenase. Endocrinology 141 1599-1607.

Lee MV, Fong EM, Singer FR \& Guenette RS 2001 Bisphosphonate treatment inhibits the growth of prostate cancer cells. Cancer Research 61 2602-2608.

Lipton A 2000 Bisphosphonates and breast carcinoma: present and future. Cancer 88 3033-3037.

Luckman SP, Coxon FP, Ebetino FH \& Russell RG 1998a Heterocycle-containing bisphosphonates cause apoptosis and inhibit bone resorption by preventing protein prenylation: evidence from structure-activity relationships in $\mathrm{J774}$ macrophages. Journal of Bone and Mineral Research 13 1668-1678.

Luckman SP, Hughes DE, Coxon FP, Graham R, Russell G \& Rogers MJ 19986 Nitrogen-containing bisphosphonates inhibit the mevalonate pathway and prevent post-translational prenylation of GTP-binding proteins, including Ras. Journal of Bone and Mineral Research 13 581-589.

Mason, JI, Bird IM \& Rainey WE 1995 Adrenal androgen biosynthesis with special attention to P450c17. Annals of the New York Academy of Sciences 774 47-58.

Mundy GR \& Yoneda T 1998 Bisphosphonates as anticancer drugs. New Enoland Journal of Medicne 339 398-400.

Nader S, Hickey R, Sellin R \& Damann N 1983 Adrenocortical carcinomas: a study of 77 cases. Cancer $\mathbf{5 2} 707-713$.
Pavlakis N \& Stockler M 2002 Bisphosphonates in breast cancer (Cochrane Review). Cochrane Database of Systematic Reviews $\mathbf{1}$ CD003474.

Rainey WE, Bird IM, Sawetawan C, Hanley NA, McCarthy JL, McGee EA, Wester R \& Mason JI 1993 Regulation of human adrenal carcinoma cell (NCI-H295) production of C19 steroids. Journal of Clinical Endocrinology and Metabolism 77 731-737.

Rainey WE, Bird IM \& Mason JI 1994 The NCI-H295 cell line: a pluripotent model for human adrenocortical studies. Molecular and Cellular Endocrinology 100 45-50.

Reszka AA, Halasy-Nagy JM, Masarachia PJ \& Rodan GA 1999 Bisphosphonates act directly on the osteoclast to induce caspase cleavage of mst1 kinase during apoptosis. A link between inhibition of the mevalonate pathway and regulation of an apoptosispromoting kinase. Journal of Biological Chemistry 274 34967-34973.

Rodan GA \& Fleisch HA 1996 Bisphosphonates: mechanisms of action. Journal of Clinical Investigation 97 2692-2696.

Rogers M, Gordon S, Benford H, Coxon F, Luckman S, Monkkonen J \& Frith J 2000 Cellular and molecular mechanisms of action of bisphosphonates. Cancer 88 2961-2978.

Russell R \& Rogers M 1999 Bisphosphonates: from the laboratory to the clinic and back again. Bone 25 97-106.

Sahni M, Guenther HL, Fleisch H, Collin P \& Martin TJ 1993 Bisphosphonates act on rat bone resorption through the mediation of osteoblasts. Journal of Clinical Investigation 91 2004-2011.

Sato M, Grasser W, Endo N, Akins R, Simmons H, Thompson DD, Golub E \& Rodan GA 1991 Bisphosphonate action. Alendronate localization in rat bone and effects on osteoclast ultrastructure. Journal of Clinical Investigation 88 2095-2105.

Schteingart DE \& Homan D 2001 Management of adrenal cancer. In Adrenal Disorders, pp 231-248. Eds AN Margioris \& GP Chrousos. Totowa, New Jersey: Humana Press Inc.

Senaratne S, Pirianov G, Mansi J, Arnett T \& Colston K 2000 Bisphosphonates induce apoptosis in human breast cancer cell lines. British Journal of Cancer 82 1459-1468.

Shipman CM, Rogers MJ, Apperley JF, Russell RG \& Croucher PI 1997 Bisphosphonates induce apoptosis in human myeloma cell lines: a novel anti-tumour activity. British Journal of Haematology $\mathbf{9 8}$ 665-672.

Sonnemann J, Eckervogt V, Truckenbrod B, Boos J, Winkelmann W \& van Valen F 2001 The bisphosphonate pamidronate is a potent inhibitor of human osteosarcoma cell growth in vitro. Anticancer Drugs 12 459-465.

Soreide JA, Brabrand K \& Thoresen SO 1992 Adrenal cortical carcinoma in Norway 1970-1984. World Journal of Surgery 16 663-667.

Staels B, Hum DW \& Miller WL 1993 Regulation of steroidogenesis in NCI-H295 cells: a cellular model of the human fetal adrenal. Molecular Endocrinology 7 423-433.

Weber MM \& Michl P 1996 Primary culture of bovine and human adult adrenocortical cells. Endocrine Methods 17 393-416.

Westley B \& Rochefort H 1980 A secreted glycoprotein induced by estrogen in human breast cancer cell lines. Cell 20 353-362.

Wudy SA, Homoki J \& Teller WM 2001 Clinical steroid analysis by gas-chromatography-mass spectrometry. In Current Practice of Gas Chromatography-Mass Spectrometry, pp 309-339. Ed WMA Niessen. New York, Basel: Marcel Dekker.

Yakatan G, Poynor W, Talbert R, Floyd B, Slough C, Ampulski R \& Benedict J 1982 Clodronate kinetics and bioavailability. Clinical Pharmacology and Therapeutics 31 402-410.

Ylitalo P, Holli K, Monkkonen J, Elo HA, Juhakoski A, Liukko-Sipi S \& Ylitalo R 1999 Comparison of pharmacokinetics of clodronate after single and repeated doses. International Journal of Clinical Pharmacology and Therapeutics 37 294-300.

Received 22 April 2002

Accepted 9 May 2002 